\title{
AN ENERGY-RESILIENT CITY, AN APPRAISAL MATRIX FOR THE BUILT ENVIRONMENT
}

\author{
SONDOSSE A. RAGHEB ${ }^{1}$, HANY M. AYAD ${ }^{2} \&$ RANIA A. GALIL $^{1}$ \\ ${ }^{1}$ Department of Architecture Engineering and Environmental Design, College of Engineering, AAST, Egypt \\ ${ }^{2}$ Faculty of Engineering, Alexandria University, Egypt
}

\begin{abstract}
The 21 st century is known as the century of the city; the world is becoming more urban with more than half of the world's population residing in cities. In this respect, a city is a complex dynamic system of interconnected urban processes. Nowadays, cities are hot spots responsible for the threatened global environment and urban life, as well as chronic stresses and vulnerabilities. Chronic energy shortage is one of the main stresses that threatens the city and puts pressure on city systems, mainly due to the impact of higher energy uses in urban areas. Vulnerabilities, stresses and adaptability are fundamental to the emerging science of resilience. While the concept of resilience is intriguing, this paper contributes to filling the theoretical gaps of the urban energy resilience by reviewing the concept of urban resilience, explaining the energy resilience principles and identifying the built environment components that can be used to help planners to enhance the city to absorb, recover and adapt to the vulnerabilities of the city. The paper concludes with suggesting an urban energy resilience matrix that addresses the energy shortage in a city to better understand and analyze the intricate issues for an energy-efficient, resilient, safer future city.

Keywords: city system, vulnerability, built environment, resilience, principles and urban energy.
\end{abstract}

\section{INTRODUCTION}

Cities all around the world are in constant evolution. The world is becoming increasingly urban, where urban areas are already hosting over half the global population. Cities are increasingly becoming highly dense, characterized by a compact urban fabric and huge urban populations. By 2025 , about $65 \%$ of the world's population is expected to live in cities, this percentage will rise to approximately $70 \%$ by 2050 [1]-[3]. The city as a complex system has become a well-recognized fact characterized by nonlinear behavior, self-organization, integration, and emergent properties, and it is far from equilibrium that leads to multiple possible outcomes permeated by uncertainty, unpredictability and discontinuities. Urban development is a complex process, involving a wide range of decision-makers, urban planners, administrative bodies, institutions and policies which focus on exploring the dynamic relations between human activities, environmental effects and potential natural disasters [4]. Due to the number of people living in cities and the complexities of city systems that are extremely vulnerable to threats, cities around the world constantly face risks and are places where stresses or shocks occur. Although urbanization involves rapid land-use planning as well as social and economic changes, the lack of fiscal, institutional resources, infrastructure and services which are inadequate to serve the increases in population densities remain a constant challenge. Also, other problems such as housing and energy shortages make cities more vulnerable [5].

Cities are shaped and consist in many dynamic internal intertwining sub-systems such as social, economic, land-use, infrastructure and transportation that have a high level of interactions with the natural environment. Each of these sub-systems has its own rules of behavior and evolution, but each is closely linked with the others. Between $60 \%$ and $80 \%$ of global energy is consumed in urban areas and given the projected increase in world's urban population, this share is expected to further increase in the future. Thinking of the city as a 
system facilities many forms of analysis for problems that appear to have no clear solution, as they are more easily approached when seen at different levels of a system [4], [6]. Therefore, an understanding of how the city copes with threats and challenges to overcome the vulnerabilities and become resilient is essential.

Resilience recently seems to be the new buzzword and paradigm in urban planning. It is following sustainability and it is already applied in different fields such as economic, engineering and ecology [7]. The concept of resilience is intellectually intriguing and widely recognized due to the exposure of cities to changes, disturbance, vulnerabilities and adaptability, which is fundamental to the emerging science of resilience and the capacity of systems to recover from change without changing its states [8], [9]. The resilience of a city is related to its built environment, ecological, social, infrastructure, and economic subsystems. Building resilience increases the ability of people, communities and systems to withstand shocks and stresses and reduce vulnerabilities to be able to bounce back quickly and stronger with unexpected outcomes. Resilience is not just for times of stress but it is also for a better, vibrant and thriving city in good and in bad times [10].

The remainder of this paper is organized as follows: section 2 gives a brief overview of the city's vulnerabilities and dimensions, and focuses on the energy crisis in the city. Section 3 elaborates on the definition of resilience in the city and, through a synthesis of related literature, presents the principles of an energy-resilient city and a theoretical framework for the resilient city that relate energy to the built environment. In section 4, different energy efficiency frameworks in urban planning are discussed. Based on these frameworks, the built environment components are selected to be used in the section 5 matrix. Section 5 explores the organization between the built environment components and the energy-resilience principles using a matrix, showing how each principle relates to the various components of the built environment selected in the previous section. The last section summarizes and concludes the paper, which studies the concept of urban energy resilience in cities.

\section{CITY VULNERABILITIES}

Cities always face natural hazards, but today's disasters are often generated by human activities. In the last three decades, it has been observed that many developed and developing countries have been impacted with disaster events in their vulnerable urban areas [11]. Vulnerability is a dynamic concept that is directly related to urban safety, a fundamental requirement for urban planning. It is the pre-event, characteristics or qualities of systems that create the potential for harm and vary significantly within a community and over time. Also, vulnerability is a function of the exposure and sensitivity of a system [12]. The concept of vulnerability has emerged in the research on the vulnerability of disaster, the ecological environment and resources, and has been applied recently in the study of global environmental change and sustainable development.

The vulnerability factors in cities are divided into structural factors and stress-driven factors. Structural factors are determined by the internal structural characteristics of the urban system which are the city size, density, built environment, socio-economic development, infrastructures, and the level of emergency response that influence a city's sensitivity to crises and risks. Whereas, stress-driven factors are those disturbances caused by sudden events, including natural disasters, accident disasters and public health emergency, which are characterized by the uncertainty of the events [11], [13].

A city as a center of production and culture faces different levels of vulnerability and the way it is perceived stimulates changes in adaptive capacity. The Grosvenor Team (2014) have identified the following five dimensions in the area of vulnerability, in which the first is stress-driven and the other four are structural [14]: 
- Climate: cities are directly threatened by physical events caused by climate change such as vulnerability to sea level change, hurricanes, typhoons, tsunamis, floods, droughts and the movement of population.

- Environment: the environment dimension measures threats to the city from pollution of all kinds and overconsumption of land resources.

- Resource: cities need access to energy, food and water. A city's population is highly vulnerable when it cannot provide in any of these resources.

- Infrastructure: cities need infrastructure to function as centers of habitation, production and consumption. Cities are ranked, according to the level of housing and transport infrastructure and basic utilities.

- Community: it is the physical events and the internal tensions due to unfairness that make cities vulnerable. The performance of cities is assessed by the affordability of housing, education and health facilities and an organized government.

The resource dimension of vulnerability is selected to cover the energy resources needed by the city. Different forms are identified in which energy exists such as heat, mechanical, chemical, nuclear and electrical energy. There are four major sources of energy which are fossil fuel, solar, nuclear and geothermal sources. The types of energy resources are categorized into renewable and non-renewable energy resources. Many studies have linked different environmental challenges to human activities put forth by the search for the production and utilization of energy resources. The value of any energy resource determines its rate of demand: production and consumption. Energy consumption and the comfort of human life are strongly linked; therefore, energy aims to meet human welfare covering household, agriculture and transport.

Energy has been identified as an irreplaceable resource for the satisfaction of the daily human needs which cannot be achieved without energy. Over seven billion people in the world need energy to survive and live comfortably. Energy crisis is any great shortfall in the supply of energy. From the various discussions, it is frequently acknowledged that environmental degradation and energy crisis result from human needs, activities and pressures on the environment and the city. Therefore, these uncertainties concerning the generation and use of energy forms provide the concept and phenomenon known as the energy crisis [15].

Energy is a major factor for development. Cities consume about $75 \%$ of the global primary energy as they require an uninterrupted supply of energy needed for transportation, industrial and commercial activities, buildings and infrastructure. Moreover, energy is needed for the raw materials, construction process and daily needs such as lighting and air conditioning. In addition, urban sprawl, increasing distances between destinations, and inefficient public transport systems prompt the overall reliance on private motorized transport which have a high energy consumption. Energy consumption must be reduced by changing consumption patterns and adopting energy-saving techniques [16]. It is established that energy-efficient planning is one of the veritable tools for tackling the phenomenon of energy crisis in a city. The process of making a resilient built environment which addresses the energy vulnerability is a complex process where many challenges are involved. The built environment, as a core component of every city, plays an essential role in the city and when moving towards the concept of sustainability and resilience in city it is important to develop the city in a way that maximizes the ability of built assets and associated support systems to function and operate during and after a disaster in order to protect people and adapt to the 
threats [17]. Understanding the resilience concept is central to understanding the sustainability concept, since sustainability addresses the need for a long-term equilibrium view of all systems. Therefore, resilience is a new way of thinking to adapt to vulnerabilities, unprecedented and unexpected changes [18].

\section{THE RESILIENT CITY}

The concept of resilience is tightly linked to sustainability as an umbrella concept that is aimed at maintaining socially, economically and environmentally desired human-environment interactions over time. Resilience is defined by many researchers and research institutions that have analyzed the concept of resilience in different contexts including ecological, engineering and social-ecological resilience. In the field of ecology, resilience is the persistence of relationships within a system and is a measure of the ability of these systems to absorb changes and disturbance and still maintain populations or state variables and accommodate future events for renewal and development in whatever unexpected form for recovery or reorganization in a new environment [19]. The engineering approach conceptualizes resilience as the system's robustness and resistance against external disruption and its capability of returning to an equilibrium state in the rare cases when the tipping points are crossed [20]. Social-ecological resilience is related to the magnitude of shock that the system can absorb and remain within a given state, the degree to which the system is capable of self-organization and the degree of the system's capacity for learning and adaptation depending on how the system organizes itself in response to management actions [21]. Furthermore, "Resilience means the ability of a system, community or society exposed to hazards to resist, absorb, accommodate to and recover from the effects of a hazard in a timely and efficient manner, including through the preservation and restoration of its essential basic structures and functions" [22, p. 92].

\subsection{Principles of an energy resilient city}

Principles for an energy-resilient city are important to prevent system failure, enable appropriate and timely action to be taken, and also to distinguish a resilient city from one that is simply livable, sustainable or prosperous. Resilient systems respond and adapt to shocks and stresses to bounce back and emerge stronger after disaster and to provide a better life; therefore, the enhanced principles help to improve the resilience of the city. The principles of resilient urban systems have been discussed by several organizations and researchers [5], [23]-[26]. There are various principles that a resilient system should possess, which are not mutually exclusive and often overlap. The following principles are required for the resiliency of the urban energy system:

- Diversity: this principle refers to the degree to which multiple functions can be used simultaneously in the system to guard supply disruptions and provide a variety of options to ensure the function of urban systems and protect the system against various threats. Diversity in an energy-resilient city is in the terms of infrastructure, land use, economy and social structure [23], [24].

- Efficiency: the proportion of energy resources provided by an urban system to the energy resource given to it as input should improve resource-use productivity and avoid waste. Also, reducing energy resources demand is important for saving energy and improving the efficiency of the city system [23], [24]. 
- Equity: this plays a crucial role for the achievement of resiliency by the fair distribution of energy resources in the community in terms of exposure to impacts related to the production and distribution of energy. This ensures the protection of marginalized and poor people to enhance social capacity to absorb and recover from stresses [23].

- Flexibility: the flexibility of a system is defined by the ability to undergo a safe failure and the willingness and ability to adopt alternative strategies in response to changing conditions due to the uncertainties in future disaster that make it difficult to achieve safe-fail design. To maintain the performance of the urban system during disaster, flexible systems have to be capable of predicting threats, to withstand failure and make some changes in its subsystems. The functional and physical elements of a flexible urban system should be designed in a way that makes it possible to disassemble and rearrange them later in a different manner through new technologies and traditional practices. In the context of energy systems, it refers to the ability to change between various configurations or adjust regulations to cope with changes [5], [23], [25].

- Resourceful: this relates to the sufficiency and the storage of energy resources that are available to be supplied at all time, in order that urban planners and decision-makers can properly understand the current state, identify vulnerabilities, prepare for, respond and recover from potential disruptions. This implies that people are able to rapidly recognize different and alternative ways to use energy resources at crisis time in order to achieve their needs during shocks and stresses [5], [23], [25].

- Redundancy: this refers to the availability of components with a number of similar functions in the urban energy system to improve its ability to absorb shocks and stresses, providing it preserves the capacity for problem solving and ensures that the exclusion of an element would not result in significant loss of functioning or the failure of the entire system. It also includes diversity, where it presents multiple ways to achieve a need and fulfil a function [5], [23]-[25].

- Agility: this represents the capacity of the system to mobilize the energy resources needed for recovery and to return the system to its normal functioning within an acceptable timely manner to avoid failures that can result in the disruption of other system functions [23].

\subsection{City resilience framework}

There are several researchers and organizations that have discussed the resilience city framework from different perspectives, these are: Conceptual framework for resilient city [27], City resilience framework [5] and Resilience Alliance framework [28]. After reviewing and analyzing the different city systems and resilience city frameworks, as a conclusion, the resilience framework proposed by the Resilience Alliance is the most comprehensive framework that represents the resilience city system well. This framework is explained below.

\subsubsection{Resilience alliance framework}

Resilience alliance, as applied to ecosystems and integrated systems of people and the natural environment, have three essential characteristics of resilience, these being 'the equilibrium' - the amount of disturbance which the system can withstand and maintain its function and structure; 'self-organization' - the capacity of self-organizations; and 'innovation' - the ability to increase the capacity for adaptation and learning [29]. 
As the city is the quintessential example of a complex, dynamic, connected and adaptive system, constantly evolving in different ways to internal interactions and the influence of external factors, four main interconnected dimensions were identified by the Resilience Alliance for the resilience of urban systems, as shown in Fig. 1. These four dimensions are metabolic flows, social dynamics, governance networks, and the built environment. To realize the resilience concept in a city, it is crucial to provide a multi-level understanding of the resilience of an urban system as a whole and its subsystems, as follows [28]:

- The metabolic flows: the role of metabolic flows is in sustaining urban functions, human well-being and quality of life in a city. All urban inhabitants depend on the consumption of the productive capacity of ecosystems located in or beyond their city to produce diverse flows of energy, material goods, and non-material services. These flows integrate into an urban system through human effort such as transportation or by natural processes such as solar radiation and precipitation, etc. Therefore, it is important to understand the critical interconnections and interdependencies of production, supply and consumption. Although, every city depends for its survival on an integrated global network of production, supply and consumption, regional self-reliance, energy efficiency and diversity of materials and its recycling can foster resilience.

- The social dynamics: The social dynamics of people as citizens, members of communities, users of services, consumers of products will live in cities especially in the developing countries. The rates of growth are related to levels of social and economic development. Cities represent massive social-ecological systems linked by common geography, culture and ecology. Communities with dense social networks, links between social order and stocks of social capital have a greater capacity for responding and adapting to environmental change.

- The governance networks: A city with good governance has mechanisms for redistributing service and human needs to a large proportion of its population. The rapid pace of cities in size and complexity and related impacts on the environment need highly dynamic networks and institutions that are able to share knowledge, adapt to social-ecological changes, and build the capacity for long-term observation, monitoring and perspectives for implementation. The governance networks, urban decision making, institutions, private sectors and civil society have to collaborate to meet the urban challenges.

- The built environment: An urban area as a complex dynamic system, is subject to a fast rate of change, chronic disturbances and complex interactions between patterns and processes which affect the capacity of urban ecosystems to generate the ecosystem services that improve the urban quality of life. The city planning, infrastructure, density of housing and economic prospects are all important for attracting industry, commerce and employment to a city. Urban planning can be defined as an expression of hypotheses about the effects of urban development on society. Understanding the urban ecosystem dynamics has the potential to contribute to urban land use plans that are proactive rather than reactive. Therefore, it is crucial to develop and change the built environment which is defined as the physical patterns of urban form and their spatial relations and interconnections, in line with the changing needs and requirements of urban populations by understanding the role of time and urban planning and its influence on the future urban options which is essential for urban resilience [28]. 


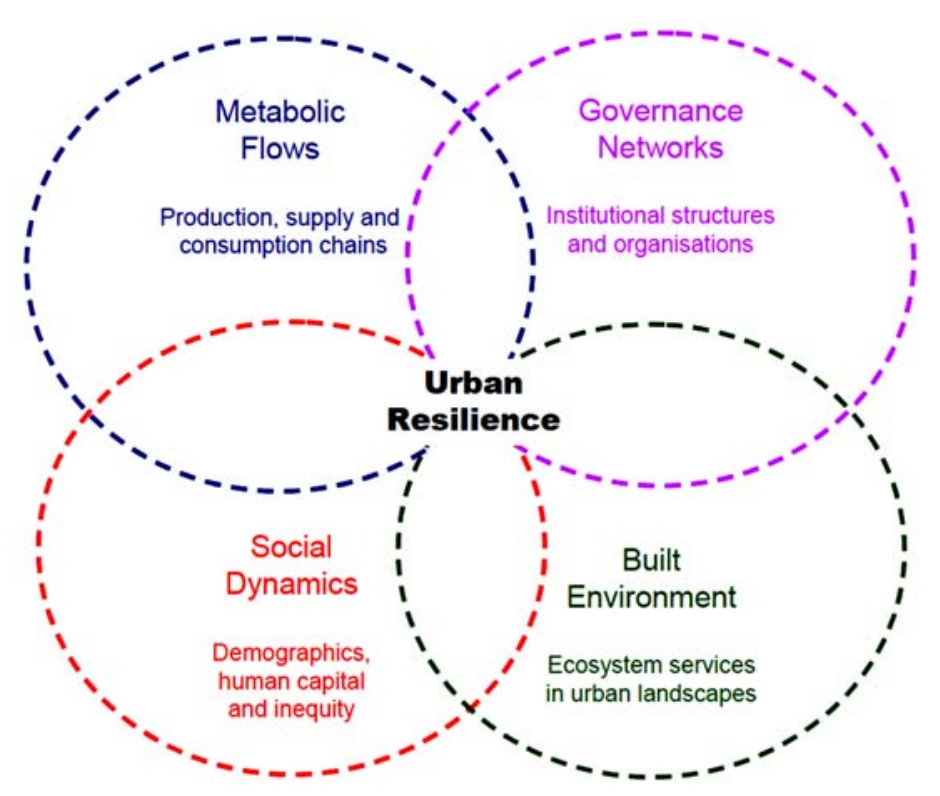

Figure 1: Resilience of urban systems dimensions. (Source: Resilience Alliance [28].)

\section{ENERGY EFFICIENCY IN URBAN PLANNING}

The Resilience Alliance integrate and connect the built environment dimension with the metabolic flow; this is the main scope of this paper. Furthermore, the interconnection of vulnerability and urban systems is an important component in urban resilience. The metabolic flows that cover energy resources and which represent one of the components constituting the urban resilience framework, was mentioned in relation to the urban system and its subsystem and the built environment to help cities withstand and cope with vulnerabilities and risks.

The followings are some energy efficiency frameworks suggested by urban planning experts:

- Energy Efficient Urban Planning training workshop that focused on various aspects of energy efficient city to integrate energy efficiency in urban planning and design. The workshop defined the following principles which form the basis for the energy efficient urban planning guidelines at a city, neighborhood and plot level [30]: context, urban structure, urban morphology, building typology and renewable energy.

- The Energy Sector Management Assistance Program (ESMAP) and The World Bank Group highlighted that to develop energy efficient urban forms, stakeholders must integrate spatial planning and all essential urban infrastructures policies from the metropolitan level down to the neighborhood scale. And they proposed the key principles to promote Energy Efficient Urban Forms: Implement Compact Urban Growth Policies and Regulations; Develop Dense and Interconnected Networks of Streets; Integrate Spatial, Transportation, and Infrastructure Plans; Ensure Accessible Green Spaces; 
- Develop Small Blocks with Diversified Uses; Establish Mixed-Use Developments; Design Streets for People, not for Cars; and Maximize the Potential of Bioclimatic Design [31].

- Energy Efficient Strategies in Urban Planning proposed some actions towards energy efficient strategies and integrating them in urban planning. Some strategies are included for energy efficiency and integrating them into urban planning which could be implemented in new or existing cities in the context of building an overall vision for urban growth sensitive to energy efficiency, these being: urban pattern, land use distribution and home-work trip, road and transportation network, buildings and renewable energy [32].

- Energy efficiency in the construction sector in the Mediterranean suggested that the principles of energy efficiency in urban planning are: energy, natural materials, infrastructure, transportation, buildings and land use [33].

Based on the analysis of the previous energy efficient frameworks shown in (Table 1), there are five built environment components - land use, urban morphology, buildings, transportation, and infrastructure - which are selected due to their importance and similarity in all the discussed energy-efficient frameworks in urban planning.

\section{PROPOSED URBAN ENERGY RESILIENCE MATRIX}

Cities are the major loci of global energy consumption. Despite the importance of energy for the effective functioning of cities, there is a gap in the urban literature regarding the definition of energy resilience and the development of a framework for its assessment [20].

Therefore, there is a need for comprehensive guidance for urban energy resilience which links the energy resilience principles with the built environment components, divided into sub-components derived from the literature [23]-[26]. This is provided in the form of a matrix (see Table 2).

The idea is to relate each energy resilience principle to the built environment component discussed in section 4 to help the planner and decision-makers, and to provide the means by which the built environment can respond to the energy resilience. It can be shown from this matrix that the efficiency principle is the most used due to its strong relation and integration to the energy resources, as it is responsible for improving the use of resources and reducing its consumption to save energy and providing efficiency in the built environment. For instance, street connectivity is a sub-component under the urban morphology that can enhance the diversity and efficiency of the energy system. This matrix clarifies and summarizes the relationships between the built environment components and the energy resilience principles to enhance resilience to energy stresses in the city.

\section{CONCLUSION}

Resilience thinking is rapidly gaining ground in science. Cities are significantly more vulnerable than before and face different shocks, pressures and stresses. Energy crisis is one of the main vulnerabilities that threatens the city. Nowadays, urban energy resilience is an emerging field within the broader context of urban resilience. Although global energy is consumed in cities, energy resilience as a strand of resilience in urban studies literature is very limited. Therefore, urban energy resilience becomes a crucial topic to be investigated. Resilience as a strategic concept is complex, dynamic and non-linear. It is based on the idea 
of networks, self-renewal and survival to deal with vulnerability, uncertainty and sudden disturbance. It is the capacity of a system to resist, recover, adapt, respond and prepare for risks and vulnerabilities [7]. The concept of resilience deeply affects and is a complex, multi-dimensional challenge for urban planning. The resilient concept draws on the perspective of cities as complex adaptive systems, developing and framing ways of assessing and responding to urban vulnerability, shocks and stresses and identifying and offering strategies and principles and frameworks intended for tackling vulnerabilities. This

Table 1: Built environment components in different frameworks.

\begin{tabular}{|c|c|c|c|c|c|c|c|c|}
\hline & $\begin{array}{l}\text { Land } \\
\text {-use }\end{array}$ & $\begin{array}{l}\text { Urban } \\
\text { Morph- } \\
\text { ology }\end{array}$ & Buildings & $\begin{array}{l}\text { Transport- } \\
\text { ation }\end{array}$ & $\begin{array}{l}\text { Infrastr- } \\
\text { ucture }\end{array}$ & $\begin{array}{l}\text { Renew- } \\
\text { able } \\
\text { Energy }\end{array}$ & Emissions & Context \\
\hline $\begin{array}{l}\text { EE } \\
\text { Urban } \\
\text { planning } \\
\text { training } \\
\text { workshop } \\
\text { by MED- } \\
\text { ENEC, } \\
2013\end{array}$ & & & & & & & & \\
\hline $\begin{array}{l}\text { ESMAP } \\
\& \text { The } \\
\text { World } \\
\text { Bank } \\
\text { program }\end{array}$ & & & & & & & & \\
\hline $\begin{array}{l}\text { EE } \\
\text { Strategies } \\
\text { in urban } \\
\text { planning } \\
\text { proposal } \\
\text { by Khalil }\end{array}$ & & & & & & & & \\
\hline $\begin{array}{l}\text { EE in the } \\
\text { constructi } \\
\text { on sector } \\
\text { by MED- } \\
\text { ENEC, } \\
2014\end{array}$ & & & & & & & & \\
\hline
\end{tabular}

Table 2: Urban energy resilience principles matrix.

\begin{tabular}{|c|c|c|c|c|c|}
\hline \multirow{2}{*}{$\begin{array}{l}\text { Energy } \\
\text { Resilience } \\
\text { Principles }\end{array}$} & \multicolumn{5}{|c|}{ Built Environment Components } \\
\hline & Land-use & $\begin{array}{c}\text { Urban } \\
\text { Morphology }\end{array}$ & Buildings & Transportation & Infrastructure \\
\hline Diversity & $\begin{array}{l}\text { - Multi- } \\
\text { functionality } \\
\text { of urban } \\
\text { space } \\
\text { - Mixed-use } \\
\text { development }\end{array}$ & $\begin{array}{l}\text { - Connectivity } \\
\text { (number of } \\
\text { intersections, } \\
\text { etc.) } \\
\text { - Street systems } \\
\text { (grid, } \\
\text { curvilinear, } \\
\text { etc.) } \\
\text { - Size of urban } \\
\text { blocks }\end{array}$ & $\begin{array}{l}\text { - District energy } \\
\text { systems } \\
\text { - Size \& } \\
\text { orientation } \\
\text { - Shading }\end{array}$ & $\begin{array}{l}\text { - Infrastructure } \\
\text { for active } \\
\text { transportation } \\
\text { modes } \\
\text { - Public } \\
\text { transportation } \\
\text { Pedestrian } \\
\text { walkways }\end{array}$ & $\begin{array}{l}\text { - Building } \\
\text { integrated } \\
\text { photovoltaic } \\
\text { - Surface albedo } \\
\text { enhancement } \\
\text { (pavements) } \\
\text { - Street lighting }\end{array}$ \\
\hline
\end{tabular}


Table 2: Continued.

\begin{tabular}{|c|c|c|c|c|c|}
\hline & Land-use & $\begin{array}{c}\text { Urban } \\
\text { Morphology }\end{array}$ & Buildings & Transportation & Infrastructure \\
\hline Efficiency & $\begin{array}{l}\text { - Mixed-use } \\
\text { development } \\
\text { - Housing-job } \\
\text { proximity }\end{array}$ & $\begin{array}{l}\text { - Development } \\
\text { pattern (sprawl, } \\
\text { compact, etc.) } \\
\text { - Density } \\
\text { (housing, } \\
\text { population) } \\
\text { - Connectivity } \\
\text { (number of } \\
\text { intersections, } \\
\text { etc.) } \\
\text { - Street systems } \\
\text { (grid, etc.) } \\
\text { - Size of urban } \\
\text { blocks }\end{array}$ & $\begin{array}{l}\text { - Redesign and } \\
\text { refurbishment } \\
\text { (retrofit) } \\
\text { - Net-zero energy } \\
\text { buildings } \\
\text { - Pooling of the } \\
\text { built environment } \\
\text { - District energy } \\
\text { systems } \\
\text { - Size \& } \\
\text { orientation } \\
\text { - Shading } \\
\text { - Green area ratio } \\
\text { (building } \\
\text { envelope) } \\
\text { - Green wall and } \\
\text { roof } \\
\text { - Enhancing energy } \\
\text { efficiency } \\
\text { through } \\
\text { technology }\end{array}$ & $\begin{array}{l}\text { - Infrastructure } \\
\text { for active } \\
\text { transportation } \\
\text { modes } \\
\text { - Size of cars } \\
\text { (family } \\
\text { number) } \\
\text { - Enhancing } \\
\text { energy } \\
\text { efficiency } \\
\text { through } \\
\text { technology }\end{array}$ & $\begin{array}{l}\text { - Building } \\
\text { integrated } \\
\text { photovoltaic } \\
\text { - Surface albedo } \\
\text { enhancement } \\
\text { (pavements) } \\
\text { - Street lighting } \\
\text { - Parks and open } \\
\text { spaces } \\
\text { - Enhancing } \\
\text { energy } \\
\text { efficiency } \\
\text { through } \\
\text { technology }\end{array}$ \\
\hline Equity & $\begin{array}{l}\text { - Mixed-use } \\
\text { development } \\
\text { - Housing-job } \\
\text { proximity }\end{array}$ & $\begin{array}{l}\text { - Density } \\
\text { (housing, } \\
\text { population) }\end{array}$ & & $\begin{array}{l}\text { - Infrastructure } \\
\text { for active } \\
\text { transportation } \\
\text { modes } \\
\text { - Size of cars }\end{array}$ & \\
\hline Agility & $\begin{array}{l}\text { Housing-job } \\
\text { proximity }\end{array}$ & $\begin{array}{l}\text { - Development } \\
\text { pattern } \\
\text { (compact, etc.) } \\
\text { - Density } \\
\text { (housing, } \\
\text { population) } \\
\text { Connectivity } \\
\text { (number of } \\
\text { intersections, } \\
\text { etc.) } \\
\text { - Street systems } \\
\text { (grid, etc.) }\end{array}$ & & & \\
\hline Flexibility & $\begin{array}{l}\text { - Multi- } \\
\text { functionality } \\
\text { of urban } \\
\text { space }\end{array}$ & & & $\begin{array}{l}\text { Diverse and } \\
\text { Affordable } \\
\text { transport }\end{array}$ & $\begin{array}{l}\text { - Flexible } \\
\text { infrastructure } \\
\text { - Sufficient } \\
\text { Affordable } \\
\text { energy supply }\end{array}$ \\
\hline Redundancy & & & $\begin{array}{l}\text { - Enhancing energy } \\
\text { efficiency } \\
\text { through } \\
\text { technology }\end{array}$ & $\begin{array}{l}\text { Enhancing } \\
\text { energy } \\
\text { efficiency } \\
\text { through } \\
\text { technology } \\
\text { Effective } \\
\text { Transport } \\
\text { - Diverse } \\
\text { Affordable } \\
\text { transport }\end{array}$ & $\begin{array}{l}\text { Enhancing } \\
\text { energy } \\
\text { efficiency } \\
\text { through } \\
\text { technology } \\
\text { Flexible } \\
\text { infrastructure }\end{array}$ \\
\hline Resourceful & & & $\begin{array}{l}\text { - Building codes } \\
\text { - Rating tools }\end{array}$ & $\begin{array}{l}\text { Effective } \\
\text { Transport }\end{array}$ & \\
\hline
\end{tabular}


paper proposes an urban energy resilience matrix that relates the energy resilience principles - diversity, efficiency, equity, agility, flexibility, interdependence, redundancy and resourcefulness - with the built environment components - urban morphology, buildings, land-use, transportation and infrastructure. This matrix seeks to integrate urban energy and resilience to elaborate on the concept of urban energy resilience to serve for assessing urban energy resilience and to identify gaps to enable planners and decision-makers to make cities more resilient.

\section{REFERENCES}

[1] Li, F. et al., Measurement indicators andan evaluation approach forassessing urban sustainable development: A case study for China's Jining City. Landscape and Urban Planning, pp. 134-142, 2009.

[2] Silva, J.D. et al., A systems approach to meeting the challenges of urban climate change. International Journal of Urban Sustainable Development, pp. 1-21, 2012.

[3] UNEP, Integration the environment in urban planning and management. Key principles and approaches for cities in the 21st century. UNON: Nairobi, 2013.

[4] Zhao, P. et al., Understanding resilient urban futures: A systemic modelling approach. Sustainability, pp. 3202-3223, 2013.

[5] The Rockefeller Foundation, Arup, City Resilience Index: City Resilience Framework, The Rockefeller Foundation: New York, 2014.

[6] Miyamoto, K. \& Paez, A., Urban and community planning. Civil Engineering, I, pp. 63-85, 2009.

[7] Stumpp, E.-M., New in town? On resilience and "Resilient Cities". Cities, pp. 164166, 2013.

[8] Ahren, J., From fail-safe to safe-to-fail: Sustainability and resilience in the new urban world. Landscape and Urban Planning, pp. 341-343, 2011.

[9] Malalgoda, C., Amaratunga, D. \& Haigh, R., Challenges in creating a disaster resilient built environment. Procedia Economics and Finance, pp. 736-744, 2014.

[10] Tyler, S. et al., Planning for Urban Climate Resilience: Framework and Examples from the Asian Cities Climate Change Resilience Network, Climate Resilience in Concept and Practice: ISET Working Paper 3, 2010.

[11] Gencer, E., natural disasters, urban vulnerability, and risk management: A theoretical overview. The Interplay between Urban Development, Vulnerability, and Risk Management. A Case Study of the Istanbul Metropolitan Area, Springer: Berlin, pp. 7-43, 2013.

[12] Cutter, S.L. et al., A place-based model for understanding community resilience to natural disaster. Global Environmental Change, pp. 598-606, 2008.

[13] Chunliang, X. et al., "Vulnerability of large city and its implication in urban planning: A perspective of intra-urban structure. Chinese Geographical Science, pp. 204-210, 2011.

[14] The Grosvenor Team, Resilient Cities: A Grosvenor Research Report, Grosvenor Group Limited, Wales, 2014.

[15] Festus, M.O. \& Ogoegbunam, O.B., Energy crisis and its effects on national development: The need for environmental education in Nigeria. British Journal of Education, pp. 21-37, 2015.

[16] UN-Habitat, Energy, 2012, https://unhabitat.org/urban-themes/energy/.

[17] Malalgodaa, C., Amaratungab, D. \& Haighb, R., Challenges in creating a disaster resilient built environment. Procedia Economics and Finance, pp. 736-744, 2014. 
[18] Ahern, J., Planning and design for sustainable and resilient cities: Theories, strategies and best practices for green infrastructure. Water Centric Sustainable Communities: Planning, Retrofitting, and Building the Next Urban Environment, John Wiley \& Sons Inc.: New Jersey, pp. 135-176, 2010.

[19] Holling, C.S., Resilience and stability of ecological systems. Annual Review of Ecology and Systematics, 4, pp. 1-23, 1973.

[20] Sharifi, A. \& Yamagata, Y., A conceptual framework for assessment of urban energy resilience. Energy Procedia, pp. 2904-2909, 2015.

[21] Lloyd, M.G., Peel, D. \& Duck, R.W., Towards a social-ecological resilience framework for coastal planning. Land Use Policy, pp. 925-933, 2013.

[22] UNISDR, Making Cities Resilient Report 2012. My city is getting ready! A global snapshot of how local governments reduce disaster risk, UNISDR, New York, 2012.

[23] Sharifi, A. \& Yamagata, Y., Principles and criteria for assessing urban energy resilience: A literature review. Renewable and Sustainable Energy Reviews, pp. 16541677, 2016.

[24] Godschalk, D.R., Urban hazard mitigation: Creating resilient cities. Natural Hazards Review, pp. 136-143, 2003.

[25] Spaans, M. \& Waterhout, B., Building up resilience in cities worldwide - Rotterdam as participant in the 100 Resilient Cities Programme. Cities, pp. 109-116, 2017.

[26] Foster, H.D., The Ozymandias Principles: Thirty-One Strategies for Surviving Change, UBC Press: Victoria, 1997.

[27] Jabareen, Y., Planning the resilient city: Concepts and strategies for coping with climate change and environmental risk. Cities, pp. 220-229, 2013.

[28] Resilience Alliance, Urban Resilience Research Prospectus: A Resilience Alliance Initiative for Transitioning Urban Systems towards Sustainable Futures, CSIRO, Australia, 2007.

[29] Penga, C. et al., A review of the theory and practice of regional resilience. Sustainable Cities and Society, pp. 86-96, 2017.

[30] MED-ENEC, Energy Efficiency Urban Planning Guidelines for MENA Region, October 2013, http://www.med-enec.eu. Accessed on 9 Jan. 2017.

[31] ESMAP, Planning Energy Efficient and Livable Cities. Mayoral Guidance Note \#6, The World Bank, Washington, DC, 2014.

[32] Khalil, H., Energy efficiency strategies in urban planning of cities. Energy Efficiency in the Urban Environment, CRC Press: Boca Raton, pp. 27-60, 2015.

[33] MED-ENEC, Sustainable energy in new urban communities. Urban Concept, 2014, http://www.med-enec.eu. Accessed on: 11 Jan. 2017. 